\title{
PENINGKATAN KREATIVITAS SISWA KELAS 4 SD MELALUI MODEL PEMBELAJARAN CONTEXTUAL TEACHING AND LEARNING (CTL)
}

\author{
Renny Setyowati, Romirio Torang Purba \\ Surel: 292013018@ student.uksw.edu
}

\begin{abstract}
This study aims to improve the creativity of science students learning grade 4 SDN Jatirunggo 02 Pringapus through learning models Contextual Teaching And Learning (CTL). This research is a classroom action research (PTK) using spiral model from Stephen Kemmis and Robin Mc Taggart which is done in two cycles. The subjects of this study were 4 grade students of SDN Jatirunggo 02 Pringapus, consisting of 33 students, ie 13 male students and 20 female students. Technique of collecting data in the form of observation technique. Data analysis technique used is descriptive comparative. The results show that the creativity of fourth grade students can be improved through CTL Learning Model.
\end{abstract}

Keywords: Creativity, Contextual Teaching And Learning (CTL)

\begin{abstract}
ABSTRAK
Penelitian ini bertujuan untuk meningkatkan kreativitas belajar IPA siswa kelas 4 SDN Jatirunggo 02 Pringapus melalui model pembelajaran Contextual Teaching And Learning (CTL). Penelitian ini merupakan penelitian tindak kelas (PTK) yang menggunakan model spiral dari Stephen Kemmis dan Robin Mc Taggart yang dilaksanakan dalam dua siklus. Subjek penelitian ini adalah siswa kelas 4 SDN Jatirunggo 02 Pringapus, yang terdiri dari 33 siswa, yakni 13 siswa laki-laki dan 20 siswa perempuan. Teknik pengumpulan data berupa teknik observasi. Teknik analisis data yang digunakan adalah deskriptif komparatif. Hasil penelitian menunjukkan bahwa kreatifitas siswa kelas 4 SD dapat ditingkatkan melalui Model Pembelajaran CTL.
\end{abstract}

Kata Kunci: Kreativitas, Contextual Teaching And Learning (CTL)

\section{PENDAHULUAN}

Ciri anak kreatif dapat ditinjau dari dua aspek yaitu aspek kognitif dan aspek afektif (Munandar, 2010). Aspek kognitif memilki ciri-ciri aptitude, yaitu ciri-ciri yang berhubungan dengan kemampuan berpikir kreatif, yang ditandai dengan adanya keterampilan tertentu, meliputi: keterampilan berpikir lancar (fluency), keterampilan berfikir luwes (flexibility), keterampilan berfikir orisional (originality), ketrampilan mengelaborasi (elaboration), keterampilan menilai (evaluation). Lain halnya dengan aspek afektif. Aspek afektif memilki ciri-ciri non aptitude, yaitu ciri-ciri kreativitas

Program Studi PGSD Universitas Kristen Satya Wacana 
yang lebih berkaitan dengan sikap dan perasaan seseorang, yang ditandai dengan berbagai perasaan tertentu, meliputi: rasa ingin tahu, bersifat imajinatif, merasa tertantang oleh kemajuan, sifat berani mengambil resiko, sifat menghargai.

Berdasarkan hasil wawancara terhadap guru kelas 4 SDN Jatirunggo Kecamatan Pringapus Kabupaten Semarang semester 2 Tahun ajaran 2016/2017, ditemukan bahwa menurut guru ada 19 siswa $(57,58 \%)$ siswa yang terindikasi belum menunjukkan kreativitasnya dan ada 14 (42,42\%) siswa yang terindikasi sudah menunjukkan kreativitas.

Data ini didukung hasil observasi awal yang menunjukkan perilaku siswa yang cenderung hanya mencatat, kurangnya kesempatan bagi siswa untuk bertanya atau mengungkapkan pendapatnya, pembelajaran yang dilakukan hanya berbasis pada buku saja dengan cara mengerjakan soal-soal dan tugas yang ada di buku tersebut. Selain itu, siswa juga tidak mendapat kesempatan untuk belajar secara langsung melalui kegiatan pengamatan atau percobaan dalam memperoleh pengetahuannya. Ini artinya, ada permasalahan kreativitas pada siswa kelas 4 SDN Jatirunggo Kecamatan Pringapus Kabupaten Semarang.

Pembelajaran perlu dirancang dengan baik supaya dapat menghasilkan output yang berkualitas dan memiliki kreativitas tinggi.
Kompenen utama pembelajaran berupa materi, pendekatan pembelajaran, metode yang akan digunakan, media, dan alat peraga yang mendukung pembelajaran. Proses pembelajaran IPA demikian akan menjadikan siswa berpikir kritis, aktif, dan kreatif dalam meningkatkan kreativitas belajar yang lebih baik. Pembelajaran yang mengaitkan siswa dengan pengalaman yang ada di lingkungan sekitar mereka dan mengarahkan menemukan sendiri pengetahuannya. Pengetahuan dan keterampilan yang diperoleh bukan hasil mengingat fakta-fakta maupun teori yang bersifat hafalan tetapi hasil dari proses menemukan sendiri. Dengan demikian, model yang tepat untuk digunakan adalah model pembelajaran Contextual Teaching and Learning (CTL).

Menurut Hamdayama (2014), CTL adalah suatu model pembelajaran yang menghadirkan dunia nyata ke dalam kelas dan mendorong siswa membuat hubungan antara pengetahuan yang dimilikinya dengan penerapannya dalam kehidupan sehari-hari, siswa memperoleh pengetahuan dan keterampilan dalam konteks yang terbatas sedikit demi sedikit, dan dari proses merekonstruksi sendiri, siswa dibekali dalam memecahkan masalah kehidupannya sebagai anggota masyarakat.

Dengan

demikian pembelajaran di sekolah tidak hanya difokuskan pada pembekalan 
kemampuan yang bersifat teoritis saja, tetapi bagaimana agar pengalaman belajar yang dimiliki siswa senantiasa terkait dengan permasalahan-permasalahan aktual yang terjadi di lingkungannya, mendapatkan gambaran nyata dari materi yang mereka pelajari dengan kehidupan mereka sehari-hari dan tingkat pemahaman mereka terhadap materi akan menjadi lebih baik. Apabila pemahaman siswa terhadap materi semakin baik maka hal ini akan memberikan dampak yang signifikan dalam meningkatkan kreativitas belajar.

Rekomendasi penggunaan CTL di kelas 4 SDN Jatirunggo didasarkan pada telaah hasil-hasil penelitian sebelumnya (Rika, 2010; Dewi, 2011; Yesi, 2016; Anna,2014; Ima, 2016; Kula, 2013; Rikhe, 2012; Winarti, 2015; Anik, 2013; Rostiecha, 2016; Lilik, 2014; Suntini, 2016; Sri, 2013; Chumairoh, 2012; Yulia, 2014; Martanti, 2014) yang menunjukkan bahwa model Contextual Teaching and Learning (CTL) dapat meningkatkan hasil belajar siswa dan kreativitas belajar siswa. Itu artinya, selain dapat meningkat hasil belajar siswa, model Contextual Teaching and Learning (CTL) juga terbukti dapat meningkatkan kreativitas belajar siswa.

\section{METODE PENELITIAN}

$\begin{array}{ccr}\text { Jenis } & \text { penelitian } & \text { yang } \\ \text { digunakan } & \text { adalah } & \text { Penelitian }\end{array}$

Tindakan Kelas (PTK). Menurut Kunandar (2011), penelitian tindakan kelas ber tujuan untuk memperbaiki mutu praktik pembelajaran di kelas.

Menurut Kemmis dan Mc Taggart (dalam Kunandar, 2011) dinyatakan bahwa penelitian tindakan kelas dilakukan melalui proses yang dinamis dan komplementari yang terdiri dari tiga prosedur tindakan yaitu perencanaan, tindakan dan observasi, dan refleksi. Prosedur penelitian tindakan kelas yang digunakan dapat dilihat pada Gambar 1.

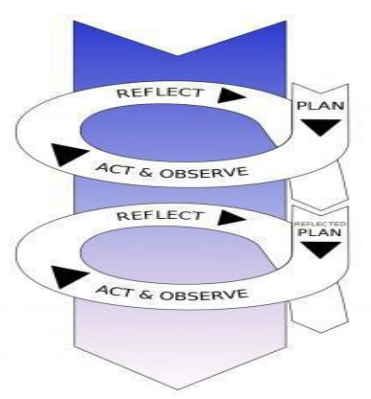

\section{Gambar 1. Prosedur PTK}

Penelitian ini dilaksanakan pada semester II tahun ajaran 2016/2017 di kelas 4 SDN Jatirunggo 02 Pringapus pada tanggal 26 April sampai 29 April. Subjek penelitiannya adalah siswa kelas 4 SDN Jatirunggo 02 Kecamatan Pringapus Kabupaten Semarang yang berjumlah 33 siswa 13 laki-laki dan 20 perempuan.

Jenis data penelitian ini berupa data primer yaitu data yang diperoleh langsung dari siswa dan dari hasil observasi guru. Teknik untuk mengumpulkan datanya menggunakan teknik observasi. 
Instrumen yang digunakan dalam penelitian ini merupakan lembar observasi yang telah diuji validitasnya dengan menggunakan validitas konstruk. Untuk menguji validitas konstruk sebuah instrumen penelitian, maka dapat dilakukan dengan menggunakan pendapat para ahli (judgment experts). Oleh karena itu, dalam hal ini setelah instrumen dikonstruksi tentang aspek-aspek yang akan diukur dengan berlandaskan teori tertentu, maka instrumen penelitian tersebut selanjutnya dikonsultasikan dengan ahli (Sugiyono, 2010).

Dalam penelitian tindakan kelas, indikator keberhasilan tindakan secara klasikal minimal $75 \%$ dari jumlah siswa harus mencapai KKM yang ditetapkan (Tampubolon, 2014). Maka dari itu, dilakukan kesepakatan antara peneliti dengan guru kelas dalam menetapkan indikator keberhasilan tindakan secara klasikal di penelitian ini, yaitu sebesar $80 \%$ dari seluruh siswa memiliki kreativitas belajar pada kriteria tinggi di mata pelajaran IPA.

Teknik analisis data yang digunakan dalam penelitian ini berupa teknik deskriptif kuantitatif dan kualitatif. Hal ini disebabkan data yang diperoleh berdasarkan hasil observasi guru dan siswa berupa penjelasan atau keterangan yang berupa data kualitatif, sedangkan data yang diperoleh berdasarkan hasil tes berbentuk angka-angka berupa data kuantitatif.

Setelah itu, data kualitatif dan kuantitatif tersebut dianalisa dengan menggunakan analisis deskriptif komparatif dengan cara membandingkan kondisi siklusi I dan siklus II, sehingga dapat dilihat peningkatan kualitas pembelajaran dan kreativitas belajar IPA pada mata pelajaran IPA materi sumber daya alam.

\section{HASIL DAN PEMBAHASAN}

Siklus 1

Dalam tahap ini pelaksanaan yang dilakukan adalah dengan menerapkan Rencana Pelaksanaan Pembelajaran (RPP) yang telah disusun. RPP yang dibuat dibagi dalam 2 pertemuan. Secara bersamaan juga dilaksanakan observasi pelaksanaan pembelajaran CTL yang dilakukan oleh guru dan pelaksanaan pembelajaran CTL yang dilakukan oleh siswa serta observasi kreativitas siswa melalui penggunaan lembar kreativitas belajar siswa.

Kegiatan refleksi dilaksanakan setelah kegiatan pembelajaran pada siklus 1 selesai, melalui kegiatan menganalisis hasil observasi dan catatan yang diisi oleh observer. Hasil analisis yang telah dilakukan secara rinci disajikan pada tabel 1 . 
Tabel 1

Persentase Keterlaksanaan Sintaks Model CTL pada siswa Siklus 1

\begin{tabular}{lllll}
\hline \multirow{2}{*}{ Tindakan Kegiatan } & \multicolumn{3}{l}{ Sintaks Model CTL } \\
\cline { 2 - 5 } & Pertemuan 1 & \multicolumn{3}{l}{ Pertemuan 2 } \\
\cline { 2 - 5 } & Frekuensi & $(\%)$ & Frekuensi & $(\%)$ \\
\hline Terlaksana & 10 & $62,5 \%$ & 13 & $81,25 \%$ \\
\hline Tidak Terlaksana & 6 & $37,5 \%$ & 3 & $18,75 \%$ \\
\hline Jmlh Tindakan & 16 & 100 & 16 & 100 \\
\hline
\end{tabular}

Hasil dari pengamatan terhadap pelaksanaan tindakan model pembelajaran CTL pada siklus 1, meliputi penerapan langkah-langkah model pembelajaran CTL. Pada pertemuan pertama kegiatan yang dilaksanakan terdiri dari kegiatan pembelajaran melakukan persiapan, menyimak apersepsi dan motivasi, menyimak tujuan pembelajaran, dan menyimak langkah-langkah kegiatan sudah dilakukan dengan baik oleh siswa. Dalam kegiatan terdiri dari 16 kegiatan yang merupakan sintaks model pembelajaran CTL. Hampir seluruh kegiatan pada pertemuan 1 sudah dilaksanakan dengan baik oleh siswa, namun beberapa siswa masih ada yang tidak fokus pada saat melakukan pengamatan di luar kelas. Ada siswa yang tidak bekerjasama pada saat pengamatan di luar kelas. Guru mengelola waktu kurang tepat nampak siswa dan guru tidak melakukan refleksi pada akhir pembelajaran.

Pada pertemuan kedua $80 \%$ kegiatan sudah dilakukan lebih baik oleh siswa. Diantaranya siswa benarbenar mengamati beberapa sumber daya alam yang ada di lingkungan sekolah dan dapat mengelompokkan sumber daya alam tersebut termasuk sumber daya alam yang dapat diperbaharui dan tidak dapat diperbaharui. Namun masih ada beberapa kekurangan yang nampak dalam pertemuan kedua seperti dalam tahap menginterpretasikan hasil analisis siswa mengalami kesulitan karena kurangnya bimbingan dari guru.

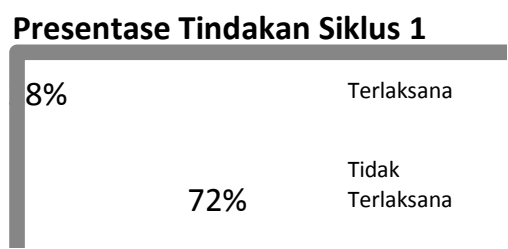

\section{Gambar 1. Diagram Keterlaksanaan Sintaks Model CTL pada siswa Siklus 1}

Dari Gambar 1 tampak bahwa tindakan model CTL yang dilakukan siswa pada kegiatan inti pertemuan 1 dan pertemuan 2 sebanyak $72 \%$ yang terlaksana dan $28 \%$ yang tidak terlaksana.

Aktivitas pembelajaran menggunakan model CTL yang dilakukan oleh guru pada siklus 1, distribusi jumlah tindakannya secara rinci dapat dilihat pada Tabel 2 . 
Tabel 2

Persentase Keterlaksanaan Sintaks Model CTL Pada Guru di Siklus 1

\begin{tabular}{lllll}
\hline Tindakan Kegiatan & \multicolumn{3}{l}{ Sintaks Model CTL } \\
\cline { 2 - 5 } & Pertemuan 1 & \multicolumn{3}{l}{ Pertemuan } \\
\cline { 2 - 5 } & Frekuensi & Presentase (\%) & Frekuensi & Presentase (\%) \\
\hline Terlaksana & 10 & $62,5 \%$ & 13 & $81,25 \%$ \\
\hline Tidak Terlaksana & 6 & $37,5 \%$ & 3 & $18,75 \%$ \\
\hline Jumlah Tindakan & 16 & 100 & 12 & 100 \\
\hline
\end{tabular}

Pada pertemuan kedua guru memilki kekurangan yaitu guru kurang membimbing siswa dalam menginterprestasikan hasil analisis di dalam kelompok sehingga siswa langsung menarik kesimpulan dari pemikiran siswa saja. Kelebihan guru pada pertemuan kedua adalah guru telah melibatkan siswa dalam kegiatan pembelajaran, guru membimbing semua siswa yang melakukan pengamatan, guru mampu menumbuhkan kreativitas belajar melalui pengamatan di luar kelas dan menciptkan pembelajaran yang aktif dan kreatif.

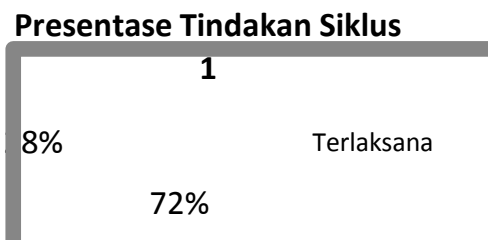

\section{Gambar 2. Diagram Lingkaran Keterlaksanaan Sintaks Model CTL pada Guru Siklus 1}

Dari gambar 2, tampak bahwa tindakan dengan Model CTL yang dilakukan guru pada kegiatan di pertemuan 1 dan pertemuan 2 sebanyak $72 \%$ yang terlaksana, dan $28 \%$ yang tidak terlaksana
Jumlah aktivitas kreativitas belajar IPA menggunakan model pembelajaran CTL diperoleh dari observasi kegiatan siswa dalam proses pembelajaran yang terdiri dari 10 indikator kreativitas belajar. Indikator tersebut diantaranya adalah Menyebutkan definisi tentang sumber daya alam hayati, Merumuskan masalah tentang sumber daya alam hayati, Merumuskan masalah tentang sumber daya alam non hayati, Mengajukan pertanyaan tentang sumber daya alam hayati, Menggolongkan sumber daya alam berdasarkan jenisnya, Mengajukan pertanyaan tentang sumber daya alam non hayati, Menggolongkan sumber daya alam berdasakan sifatnya, Menyebutkan definisi tentang sumber daya alam non hayati, Membuat atau menentukan keputusan tentang sumber daya alam hayati dan non hayati, Menilai jawaban benar tentang sumber daya alam hayati dan non hayati.

Hasil yang diperoleh dari penelitian, kreativitas belajar IPA dalam model pembelajaran CTL siswa kelas 4 SD Negeri Jatirunggo 02 Semester II tahun pelajaran 
Tabel 3

Presentase Kriteria Kreativitas Belajar IPA Melalui Model Pembelajaran Contextual Teaching and Learning Siklus 1

\begin{tabular}{l|l|l|l}
\hline $\begin{array}{l}\text { Interval Jumlah Aktivitas } \\
\text { Kreativitas }\end{array}$ & Kriteria & Frekuensi & Presentase (\%) \\
\hline $8-10$ & Tinggi & 21 & $63,64 \%$ \\
\hline $5-7$ & Sedang & 7 & $21,21 \%$ \\
\hline $2-4$ & Rendah & 5 & $15,15 \%$ \\
\hline & Jumlah & 33 & 100 \\
\hline
\end{tabular}

Berdasarkan tabel 3 maka dapat dikatakan bahwa setelah adanya tindakan melalui model pembelajaran CTL dalam pembelajaran, diketahui adanya peningkatan kreativitas siswa. Tampak bahwa ada $63,64 \% \quad(21$ siswa) dari 33 siswa masuk dalam kriteria tinggi, $21,21 \%$ (7 siswa) masuk dalam kriteria kreativitas sedang, dan 15,15\% (5 siswa) masuk dalam kriteria kreativitas rendah. Jadi pembelajaran melalui model pembelajaran CTL dapat mengembangkan kemampuan kreativitas belajar siswa. Namun, karena belum mencapai seperti target yang ditetapkan perlu dilakukan tindakan pada siklus 2. Lebih jelasnya deskripsi kreativitas pada siklus 1 akan ditunjukkan melalui Gambar 3.

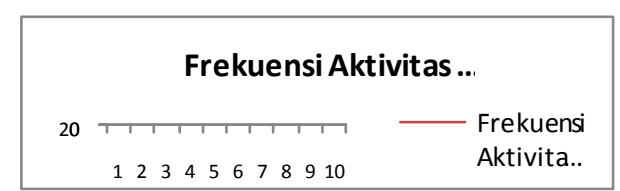

\section{Gambar 3. Grafik Garis Jumlah Aktivitas Kreativitas Belajar IPA di Siklus I}

Dari gambar 3 tampak bahwa siswa yang memiliki jumlah aktivitas kreativitas belajar terendah 3 sebanyak 3 siswa, jumlah kreativitas belajar 4 sebanyak 2 siswa, jumlah kreativitas belajar 5 sebanyak 2 siswa, jumlah kreativitas belajar 6 sebanyak 3 siswa, jumlah kreativitas belajar 7 sebanyak 2, jumlah kreativitas belajar 8 sebanyak 15 siswa, jumlah kreativitas belajar 9 sebanyak 6 siswa.

Siklus 2

Kegiatan $\begin{array}{r}\text { refleksi } \\ \text { kegiatan }\end{array}$
dilaksanakan setelah $\begin{aligned} & \text { kelan } \\ & \text { pembelajaran siklus } 2 \text { selesai, dengan }\end{aligned}$
menganalisis hasil observasi dan
catatan yang diisikan oleh observer.
Hasil dari pengamatan terhadap
pelaksanaan tindakan model
pembelajaran CTL pada siklus 2 yang
dilaksanakan melalui 2 pertemuan,
yang langsung menerapkan langkah-
langkah model pembelajaran CTL.
Pada pertemuan pertama,
100\% kegiatan sudah dilakukan lebih baik oleh siswa. Kegiatan pendahuluan terdiri dari kegiatan pembelajaran melakukan persiapan, menyimak apersepsi, dan menyimak 
tujuan pembelajaran sudah dilakukan dengan baik oleh siswa. Langkahlangkah pembelajaran yang disampaikan oleh guru juga telah disimak dan dilaksanakan dengan baik oleh siswa sampai akhir kegiatan. Dalam kegiatan inti terdiri dari 16 kegiatan, yang merupakan kegiatan tindakan model pembelajaran CTL.

Pada pertemuan kedua, $100 \%$ kegiatan sudah dilakukan lebih baik oleh siswa. Dalam kegiatan pembelajaran terdiri dari 16 kegiatan, yang merupakan kegiatan tindakan model pembelajaran CTL. Di samping itu kegiatan pembelajaran pada siklus 2 dalam pelaksanaan diantaranya siswa sudah lebih aktif dan memiliki kemampuan untuk menciptakan sesuatu yang baru yang merupakan bentuk-bentuk kreativitas belajar siswa, pada kegiatan pembelajaran siswa mampu bekerja sama dengan anggota kelompok, serta keberanian siswa sudah mulai tumbuh dalam menyampaikan pendapat, membuat pertanyaan, mencetuskan ide baik dalam diskusi kelompok maupun diskusi kelas. Keterlibatan siswa dalam kegiatan pembelajaran pun sudah tumbuh pada siklus ke 2 .

Aktivitas tindakan model pembelajaran CTL guru pada pertemuan pertama juga nampak kelebihan guru yaitu guru sudah melaksanakan pembelajaran sesuai dengan RPP menggunakan model pembelajaran CTL secara optimal. Kegiatan pada pertemuan kedua juga sudah dilaksanakan $100 \%$ oleh guru. Guru melaksanakan pembelajaran dengan tepat waktu dan menimbulkan keaktifan siswa secara optimal. Kelebihan guru pada pertemuan kedua adalah pemantauan dan bimbingan guru dalam menyusun pazzel menyeluruh dan rata kepada semua kelompok. Keseluruhan kegiatan pembelajaran pada pertemuan sudah dilaksanakan semua dengan baik.

Jumlah aktivitas kreativitas belajar IPA melalui model pembelajaran CTL diperoleh dari observasi kegiatan siswa dalam proses pembelajaran yang terdiri dari 10 indikator pertanyaan kreativitas belajar. Indikator kreativitas tersebut diantaranya Menyebutkan 3 penggunaan teknologi dalam pemanfaatan sumber daya alam, Merumuskan masalah tentang penggunaan teknologi dalam pemanfaatan sumber daya alam, Mengemukakan masalah dari sumber daya alam cara pengolahannya dengan menggunakan teknologi, Mengajukan pertanyaan tentang contoh penggunaan teknologi dalam pemanfaatan sumber daya alam, Menemukan contoh-contoh penggunaan teknologi dalam pemanfaatan sumber daya alam, Mengajukan pertanyaan hasil sumber daya alam yang telah diolah bagi kehidupan manusia, Menentukan contoh-contoh penggunaan teknologi dalam pemanfaatan sumber daya alam, Menyebutkan 3 contoh hasil 
pengolahan sumber daya alam dengan teknologi, Membuat atau menentukan keputusan tentang contoh penggunaan teknologi dalam pemanfaatan sumber daya alam, Menilai jawaban benar tentang contoh penggunaan teknologi dalam pemanfaatan sumber daya alam.

Hasil yang diperoleh dari penelitian kreativitas belajar IPA dalam model pembelajaran CTL siswa kelas 4 pada siklus 2 disajikan pada Tabel 4.

Tabel 4

Presentase Kriteria Kreativitas Belajar IPA Melalui Model Pembelajaran Contextual Teaching and Learning di Siklus 2

\begin{tabular}{llll}
\hline Interval Jumlah Aktivitas Kreativitas & Kriteria & F & $\%$ \\
\hline $8-10$ & Tinggi & 31 & $93,94 \%$ \\
\hline $5-7$ & Sedang & 2 & $6,06 \%$ \\
\hline Jumlah & & 33 & 100 \\
\hline
\end{tabular}

Berdasarkan tabel 4 maka dapat dikatakan bahwa setelah adanya tindakan melalui model pembelajaran CTL dalam pembelajaran diketahui adanya peningkatan kreativitas siswa. Tampak bahwa 93,94\% (31 siswa) dari 33 siswa masuk dalam kriteria tinggi, 6,06\% (2 siswa) masuk dalam kriteria kreativitas sedang. Hasil yang diperoleh dari penelitian kreativitas belajar IPA dalam model Model Pembelajaran CTL Siswa Kelas 4 SD Negeri Jatirunggo 02 Semester II Tahun 2016/2017 dapat disajikan dalam secara rinci melalui Gambar 4.

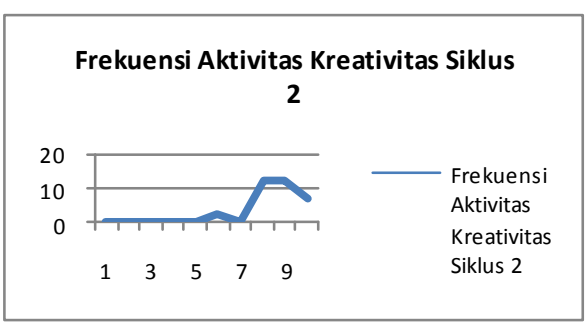

Gambar 4. Grafik Garis Jumlah Aktivitas Kreativitas Belajar IPA di Siklus 2
Dari gambar 4 tampak bahwa siswa yang memiliki jumlah kreativitas belajar terendah 6 sebanyak 2 siswa, jumlah kreativitas belajar siswa 8 sebanyak 12 siswa, jumlah kreativitas belajar 9 sebanyak 12 siswa, jumlah kreativitas belajar 10 sebanyak 7 siswa.

Perbandingan Siklus I dan Siklus II Hasil penelitian tindakan pembelajaran IPA dengan model Model Pembelajaran CTL Siswa Kelas 4 SD Negeri Jatirunggo 02 Semester II Tahun 2016/2017 menunjukkan adanya peningkatan aktivitas tindakan model pembelajaran CTL yang dilakukan oleh siswa dari siklus 1 ke siklus 2 . Hal ini ditunjukkan melalui Tabel 5. 
Tabel 5

Perbandingan Jumlah Tindakan Model Contextual Teaching and Learning (CTL) Pada Kegiatan Siswa di Siklus 1 dan Siklus 2

\begin{tabular}{lllll}
\hline \multirow{2}{*}{ Tidakan Kegiatan } & \multicolumn{2}{l}{ Sintaks Model CTL } & Siklus 2 & \\
\cline { 2 - 5 } & Siklus 1 & & Frekuensi & Presentase (\%) \\
\cline { 2 - 5 } & Frekuensi & Presentase (\%) & 100 \\
\hline $\begin{array}{l}\text { Tindakan Model Contextual } \\
\text { Teaching and Learning (CTL) } \\
\text { yang dilakukan }\end{array}$ & 26 & $81,25 \%$ & 32 & \\
\hline $\begin{array}{l}\text { Tindakan Model Contextual } \\
\text { Teaching and Learning (CTL) }\end{array}$ & 6 & & & \\
Yang Belum Dilakukan & & & & \\
\hline Jumlah Tindakan & 32 & 100 & 32 & 100 \\
\hline
\end{tabular}

Dari Tabel 5 tampak bahwa melalui Model CTL yang diberikan, ada peningkatan jumlah tindakan yang dilakukan siswa pada siklus 1 dan siklus 2, hal ini dapat dilihat melalui Gambar 5

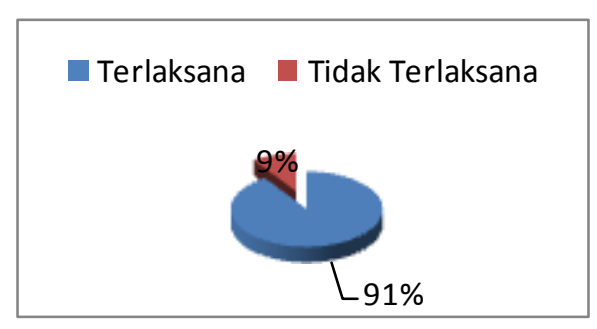

Gambar 5. Diagram Lingkaran Keterlaksanaan Sintaks Model CTL Pada Siswa di Siklus 2
Berdasarkan Gambar 5 ditunjukkan bahwa ada peningkatan jumlah tindakan yang dilakukan siswa dari siklus 1 ke siklus 2. Untuk jumlah tindakan guru dalam melaksanakan pembelajaran dengan menggunakan Model CTL yang dilakukan guru dalam siklus 1 dan siklus 2 dapat dilihat pada Tabel 6 .

Tabel 6

Perbandingan Jumlah Tindakan Model Contextual Teaching and Learning (CTL) Pada Kegiatan Guru di Siklus 1 dan Siklus 2

\begin{tabular}{|c|c|c|c|c|}
\hline \multirow{3}{*}{ Tidakan Kegiatan } & \multicolumn{4}{|c|}{ Sintaks Model CTL } \\
\hline & \multicolumn{2}{|c|}{ Siklus 1} & \multicolumn{2}{|l|}{ Siklus 2} \\
\hline & Frekuensi & Presentase (\%) & Frekuensi & Presentase (\%) \\
\hline $\begin{array}{l}\text { Tindakan Model } \\
\text { Contextual Teaching } \\
\text { and Learning (CTL) } \\
\text { yang dilakukan }\end{array}$ & 26 & $81,25 \%$ & 32 & 100 \\
\hline $\begin{array}{lr}\text { Tindakan } & \text { Model } \\
\text { Contextual Teaching } \\
\text { and Learning } \\
\text { Yang } \\
\text { Yilakukan }\end{array}$ & 6 & $18,75 \%$ & 0 & 0 \\
\hline Jumlah Tindakan & 32 & 100 & 32 & 100 \\
\hline
\end{tabular}


Dari Tabel 6 tampak bahwa jumlah tindakan yang dilakukan guru dalam melaksanakan tindakan Model CTL dari siklus 1 ke siklus 2 mengalami penambahan jumlah aktivitas, yakni jumlah kegiatan yang dilakukan dalam kegiatan inti, jumlah tindakan Model CTL yang dilakukan guru mengalami peningkatan, yang semula hanya 26 kegiatan yang dilakukan pada siklus 1, meningkat menjadi 32 kegiatan yang dilakukan pada siklus 2. Peningkatan jumlah tindakan yang dilakukan oleh guru dapat dilihat secara rinci dalam Gambar 6.

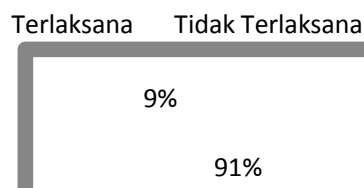

Gambar 6 Diagram lingkaran Keterlaksanaan Sintaks Model CTL Pada Guru di Siklus 2

Berdasarkan Gambar 6 tampak bahwa implementasi tindakan guru pada siklus 1 ke siklus2 mengalami peningkatan. Tindakan siklus 2 pada kegiatan inti sudah dilaksanakan semua oleh guru dengan baik. Selanjutnya perbandingan kriteria kreativitas belajar siswa dalam siklus 1 dan siklus 2 dapat dilihat pada Tabel 7 .

Tabel 7

Perbandingan Kriteria Kreativitas Belajar IPA Melalui Model Pembelajaran Contextual Teaching and Learning (CTL) di Siklus 1 dan Siklus 2

\begin{tabular}{|c|c|c|c|c|c|c|}
\hline \multirow[b]{3}{*}{ No } & \multicolumn{6}{|c|}{ Kreativitas Siswa } \\
\hline & \multicolumn{2}{|c|}{ Interval } & \multicolumn{2}{|l|}{ Siklus 1} & \multicolumn{2}{|l|}{ Siklus 2} \\
\hline & $\begin{array}{l}\text { Jumlah } \\
\text { Aktivitas } \\
\text { Kreativitas }\end{array}$ & Kriteria & Frekuensi & $\begin{array}{l}\text { Persentase } \\
(\%)\end{array}$ & Frekuensi & $\begin{array}{l}\text { Persentase } \\
(\%)\end{array}$ \\
\hline 1 & $8-10$ & Tinggi & 21 & $63,64 \%$ & 31 & $93,94 \%$ \\
\hline 2 & $5-7$ & Sedang & 7 & $21,21 \%$ & 2 & $6,06 \%$ \\
\hline 3 & $2-4$ & Rendah & 5 & $15,15 \%$ & 0 & 0 \\
\hline \multicolumn{3}{|c|}{ Jumlah } & 33 & 100 & 33 & 100 \\
\hline
\end{tabular}

Berdasarkan Tabel 7, yang menduduki kriteria kreativitas tinggi pada siklus 1 yaitu 21 siswa atau $63,63 \%$, dan pada siklus 2 yaitu 31 siswa atau 93,94\%. Sedangkan kriteria sedang pada siklus 1 yaitu 7 siswa atau $21,21 \%$, dan pada siklus 2 yaitu 2 siswa atau $6,06 \%$, selanjutnya kriteria rendah pada siklus 1 terdapat
5 siswa atau $15,15 \%$, dan pada siklus $2 \%$ atau tudak ada siswa yang bearada pada kondisi kreativitas rendah.

Pembahasan

Hasil dari penelitian yang dilakukan pada siklus 1 dan siklus 2 mengalami peningkatan baik dalam 
tindakan Model CTL pada kegiatan pembelajaran serta pada jumlah aktivitas kreativitas yang dialami siswa. Tampak pada Tabel 5 dan Tabel 6, menunjukkan perbandingan tindakan Model CTL pada kegiatan pembelajaran yang dilakukan siswa dan guru mengalami peningkatan. Kreativitas belajar IPA pada siklus 1 dan siklus 2 juga mengalami peningkatan, yang tampak pada Tabel 7. Dengan mengetahui kriteria kreativitas yang meningkat maka ditentukan juga nilai dari mean, median, dan modus. Mean merupakan jumlah keseluruhan data dibagi dengan banyaknya data. Diperoleh nilai mean pada siklus 1 yaitu 7,06 dan siklus 2 yaitu 8,67 sedangkan pengertian median adalah letak tengah data setelah data disusun menurut urutan nilai dari yang terkecil sampai terbesar, maka dapat diketahui median pada siklus 1 yaitu 8 dan siklus 2 yaitu selanjutnya modus adalah nilai yang paling sering muncul dalam data. Nilai modus pada siklus 1 yaitu 8 dan siklus 2 yaitu $8 \&$ 9 (karena sama-sama muncul sebanyak 12 kali) (Awalliudin, dkk, 2008).

Tindakan yang dipilih untuk meningkatkan kreativitas belajar IPA pada siswa kelas 4 SDN Jatirunggo 02 adalah dengan menggunakan model pembelajaran CTL. Model ini merupakan usaha untuk membuat siswa aktif bekerja sama berpikir kritis dan kreatif untuk memompa kemampuan diri, sebab siswa berusaha mempelajari konsep sekaligus menerapkan dan mengaitkannya dengan dunia nyata (Johnson, 2008). Menurut Hamdayama (2014), Contextual Teaching and Learning (CTL) adalah konsep belajar dimana guru menghadirkan dunia nyata kedalam kelas dan mendorong siswa membuat hubungan antara pengetahuan yang dimilikinya dengan penerapannya dalam kehidupan sehari-hari, siswa memperoleh pengetahuan dan ketrampilan dalam konteks yang terbatas sedikit demi sedikit, dan dari proses merekonstruksi sendiri, sebagai bekal dalam memecahkan masalah kehidupannya sebagai anggota masyarakat. Contextual Teaching and Learning (CTL) adalah konsep belajar dimana guru menghadirkan dunia nyata kedalam kelas dan mendorong siswa membuat hubungan antara pengetahuan yang dimilikinya dengan penerapannya dalam kehidupan sehari-hari (Hosnan, 2014). Penelitian tindak kelas pada siklus 1 dan siklus 2 membahas tentang sumber daya alam berdasarkan sifat dan jenisnya serta penggunaan teknologi dalam pemanfaatan sumber daya alam.

Penelitian ini dilaksanakan dengan pembentukan kelompok secara heterogen dengan cara berhitung. Hal ini sesuai dengan pendapat Slavin (2007) yang menyatakan bahwa pembagian kelompok secara heterogen bertujuan agar siswa dapat bekerja sama dan 
mengeluarkan pendapatnya. Penelitian ini dikatakan berhasil karena adanya peningkatan kreativitas dengan presentase 93,94\% lebih besar dari indikator yang ditentukan $80 \%$ dari seluruh siswa yang memiliki kreativitas belajara IPA tinggi, maka dapat dikatakan $80 \%$ siswa sudah menduduki kriteria kreativitas tinggi sehingga penelitian yang dilakukan berhasil meningkatkan krativitas belajar siswa.

Sama dengan penelitian yang dilakukan Rika (2010), Penelitian ini merupakan penelitian tindakan kelas. Percobaan dilakukan dalam tiga siklus, dengan setiap siklus terdiri dari perencanaan, tindakan, observasi, dan refleksi. Berdasarkan hasil penelitian, dapat disimpulkan bahwa kreativitas siswa dalam pembelajaran sains meningkat setelah menerapkan model pembelajaran kontekstual. Akhirnya, menjadi rekomendasi dalam pembelajaran sains dengan menggunakan model kontekstual dapat meningkatkan kreativitas belajar siswa. Dewi (2011), Hasil penelitian menunjukkan bahwa pendekatan kontekstual dapat meningkatkan kreativitas dan prestasi siswa secara signifikan. Kreativitas siswa meningkat $\geq 65 \%$ dan prestasi siswa meningkat dari $48,1 \%$ menjadi $68,9 \%$. Temuan penelitian ini sesuai dengan temuan hasil-hasil penelitian sebelumnya yang juga menunjukkan bahwa penerapan model CTL dapat meningkatkan hasil belajar siswa dan kreativitas belajar siswa. Itu artinya, selain dapat meningkat hasil belajar siswa, melalui penelitian ini juga ditunjukkan bahwa CTL juga ternyata mampu meningkatkan kreativitas siswa sekolah dasar.

\section{SIMPULAN}

Peningkatan kreativitas belajar IPA dapat diupayakan melalui model Contextual Teaching and Learning (CTL) siswa kelas $4 \mathrm{SD}$ Negeri Jatirunggo 02 Pringapus semester II tahun pelajaran 2016/2017. Hal ini ditunjukkan dari peningkatan kriteria kreativitas belajar IPA (tinggi) dari siklus $1 \mathrm{ke}$ siklus 2 yakni 63,64\% naik menjadi 93,94\%, dan kriteria kreativitas belajar IPA (sedang) dari siklus $1 \mathrm{ke}$ siklus 2 yakni $21,21 \%$ menjadi 6,06\%, dan kriteria kreativitas belajar IPA (rendah) dari siklus 1 ke siklus 2 yakni $15,15 \%$ menjadi $0 \%$.

\section{DAFTAR RUJUKKAN}

Anna, Mai, Sandhi. 2014. Peningkatan Kreativitas

Melalui Model Problem Based Learning (PBL) Dalam Pembelajaran Ips Pada Siswa Kelas IV SDN 1 Gembongan Banjarnegara. Jurnal UNY Vol. III No.13.

Anik, Soegyanti. 2013. Upaya Peningkatan Hasil Belajar IPA Dengan Menggunakan Model Pembelajaran Contextual and Teaching Learning (CTL) Pada Siswa Kelas III SDN Nginden 
Renny Setyowati: Peningkatan Kreatifitas ..

Jangkungan I / 247

Kecamatan Sukolilo Kota

Surabaya Tahun Pelajaran

2011/2012. Jurnal Penelitian

Pendidikan Guru Sekolah

Dasar Vol. 1, No. 1.

Arikunto, Suharsimi. 2014. Prosedur Penelitian Suatu Pendekatan Praktik. Jakarta: Rineka Cipta.

Awaliudin. 2008. Statistika Pendidikan. Direktorat Jenderal Pendidikan Tinggi Departemen Pendidikan Nasional.

Chumairoh, 2012. Meningkatkan Prestasi Belajar Matematika Dengan Menggunakan Pendekatan Kontekstual (Ctl) Pada Siswa Kelas IV SDN Sengi 1 Dukun Kabupaten Magelang. Jurnal UNY Vol. I No. 1.

Dewi. 2011. Peningkatan Kreativitas Belajar Matematika Melalui Model Contextual Teaching and Learning (CTL).

Hamdayama, Jumanta. 2014. Model dan Metode Pembelajaran Kreatif dan Berkarakter. Bogor: Ghalia Indonesia.

Hosnan, 2014. Pendekatan Saintifik dan Kontekstual Dalam Pembelajarann Abad 21. Bogor: Ghalia Indonesia.
Ima, Heni, Rochayati. 2016. Peningkatan Kreativitas Belajar IPA Melalui Penerapan Strategi Guided Discovery Learning. Jurnal Pendidikan Guru sekolah dasar Edisi 33.

Johnson. Elaine B. 2009. Contextual Teaching and Learning. Bandung: Mizan Learning Centre (MLC).

Kula. 2013. Penerapan Model Pembelajaran Contextual Teaching and Learning Untuk Meningkatkan Aktivitas Dan Hasil Belajar IPS Siswa Kelas V SD Negeri 060885 Medan. Jurnal Tematik Vol.003 N0.12.

Lilik, Suharnanik. 2014. Meningkatkan Hasil Belajar Siswa Pada Mata Pelajaran IPA (Pokok Bahasan Sistem Tata Surya) Melalui Pendekatan Kontekstual Pada Siswa Kelas Vic Sdn Tanggul Wetan 02 Jember. Pancaran, Vol.3, No.2, 175-184.

Martanti, Kuswandari. 2014. Peningkatan Hasil Belajar Siswa Dalam Pembelajaran IPS Dengan Contexstual Teaching Learning (CTL) Pada Siswa Kelas Iv Sdn Tirtoadi. Jurnal UNY Vol. III No. 14. 
Munandar, Utami. 2010. Pengembangan Kreativitas Anak Berbakat. Jakarta: Rineka Cipta.

Rika. 2010. Peningkatan Kreativitas Belajar Siswa Melalui Model Kontekstual.

Rikhe. 2012. Meningkatkan Hasil Belajar Siswa Pada Materi Gaya Dengan Penerapan Pendekatan Contextual Teaching and Learning (CTL) Pada Siswa Kelas IV SDN 9 Tanjung. Jurnal Inovasi Pendidikan Sains, Vol.3 No.2, 152-158.

Rostiecha, Rahayu. 2016. Peningkatan Prestasi Belajar IPA Melalui Model Contextual Teaching and Learning Pada Siswa Kelas III SD Negeri Tegalsari. Jurnal Pendidikan Guru Sekolah Dasar Edisi 3.

Slavin, Robert E. 2008. Cooperative Learning, Teori, Riset dan Praktik, terj. Nurulita Yusron. Bandung: Nusa Media.

Sugiyono. 2010. Metode Penelitian Pendidikan (Pendekatan Kuantitatif, Kualitatif, dan $R \& D$. Bandung: Alfabeta, cv.

Suntini. 2016. Penerapan Metode Pembelajaran Contextual Teaching and Learning dalam Upaya Meningkatkan Hasil Belajar IPA. Jurnal Widya Sari Volume 18/Vol 18 No 3.
Sri, Lestari. 2013. Meningkatkan Prestasi Belajar Matematika dengan Pendekatan Contextual Teaching And Learning (CTL) Pada Siswa Sekolah Dasar. Jurnal UNY Vol. II No. 10.

Tampubolo, Saur. 2014. Penelitian Tindak Kelas Untuk Pengembangan Profesi Pendidikan dan Keilmuan. Erlangga, PT. Gelora Aksara Pratama.

Winarti. 2015. Contextual Teaching and Learning (CTL) Untuk meningkatkan Kemampuan Berpikir Kreatif Siswa. JPFK VOL.1 No.1, 1-8.

Yesi, Murti, Fatmasari. 2016. Peningkatan Kreativitas Belajar IPS Melalui Metode Mind Map siswa Kelas V SD negeri Jeruksari. Jurnal Pendidikan Guru Sekolah Dasar Edisi 33.

Yulia, Dwi, Ernawati. 2014. Peningkatan Prestasi Belajar IPA Menggunakan Model Contextual Teaching And Learning. Jurnal UNY Vol. III No. 16. 